\title{
Professor Luiz Carlos, Meu Professor
}

\author{
Léia Priszkulnik \\ Instituto de Psicologia-USP
}

\begin{abstract}
Quarta-feira, 15 de outubro de 2003. Dia difícil de ser lembrado. De manhã cedo recebi a notícia da morte do Professor Luiz Carlos, notícia que me causou um forte impacto. Como? Ele morreu? Várias notícias que recebemos na vida vêm de maneira inesperada, mas essa... ele estava bem, trabalhando...
\end{abstract}

O que escrever sobre ele? Que rumo tomar? Depois de voltas e mais voltas, opto por escrever sobre o meu professor Luiz Carlos.

Lembrar dele é lembrar do meu percurso universitário e intelectual. Luiz Carlos foi meu professor no Curso de Graduação em Psicologia. Cursei uma disciplina que ele ministrava durante o Curso de Pós-Graduação. Tive o privilégio de contar com ele na Banca do meu Mestrado, do meu Doutorado e do meu Concurso de efetivação como docente do Departamento de Psicologia Clínica. Lembro da forma como ele falou, nessas três ocasiões, do meu trabalho e das minhas pesquisas. Palavras de apoio e de estímulo, mas também palavras de incentivo para uma ousadia maior no campo psicanalítico. Lembro também das vezes em que o procurei para aclarar algumas dúvidas teóricas. Suas palavras tinham um peso muito grande para mim. Suas explanações abriam espaços novos a serem explorados e percorridos.

Pude ouvi-lo muitas ve zes em palestras e conferências na Universidade e fora dela. Algumas das apresentações que assisti foram simplesmente magistrais. Nelas, Luiz Carlos parecia iluminado, suas palavras iam abordando e desenvolvendo o tema de forma muitas vezes inusitada.

Tive a oportunidade de contar com sua presença na Banca de Mestrado de uma orientanda. As pontuações muito precisas e o jeito elegante de 
comentar o trabalho de um outro, faziam parte de seu estilo nessas ocasiões. Tive a oportunidade de ser chamada por ele para participar de Bancas de orientandas dele. Nas duas ocasiões, também com seu jeito elegante de reconhecer o trabalho de um outro, me disse que pensara no meu nome por saber que eu conhecia os escritos de Freud e que, com isso, poderia enriquecer as respectivas argüições.

Mas, também, tive o privilégio de tê-lo como colega de Departamento. Aquele colega que não falava muito nas reuniões, mas quando falava, suas frases tinham uma clareza e uma força muito grandes. O seu estilo elegante também se fazia presente nessas ocasiões.

Ele foi uma figura de destaque na luta para que as investigações em Psicanálise fossem aceitas e reconhecidas no meio acadêmico. Ele dizia da importância dessa luta frente a um ambiente universitário impregnado pelos modelos de pesquisa das ciências exatas e biológicas. Lembro das palavras de apoio que recebi durante a argüição do Doutorado, pois apresentei um caso único, o caso exemplar, para defender minha tese.

Além dessa importância como docente universitário, psicanalista e pesquisador, foi uma figura muito importante para o ensino da obra de Lacan, não só na Universidade como também no país. Foi um dos introdutores desse ensino nos idos de 1975, época em que fundou o primeiro círculo hcaniano do Brasil, o Centro de Estudos Freud ianos (CEF), junto com outros três colegas também psicanalistas.

A ausência de Luiz Carlos Nogueira deixa uma lacuna muito grande. Seu nome já está inscrito na História do Departamento de Psicologia Clínica e do Instituto de Psicologia da USP. Além disso, seu nome também já está inscrito na História da Psicanálise Llacaniana no Brasil e no mundo, fato que se tornou conhecido desde que foi citado como um dos fundadores do primeiro círculo lacaniano brasileiro no verbete "Brasil", do Dicionário de Psicanálise de Elizabeth Roudinesco e Michel Plon, lançado em 1997 na França e, em 1998, no país.

Agora que não podemos contar mais com sua presença, com suas palavras firmes e elegantes e com seus ensinamentos, a saudade e alguns sen- 
timentos, até contraditórios, só conseguem expressão através das palavras de um poeta...

\section{A Um Ausente}

Tenho razão de sentir saudade, tenho razão de te acusar.

Houve um pacto implícito que rompeste e sem te despedires foste embora.

Detonaste o pacto.

Tenho razão para sentir saudade de ti, de nossa convivência em falas camaradas, simples apertar de mãos, nem isso, voz modulando sílabas conhecidas e banais que eram sempre certeza e segurança.

Sim, tenho saudades.

Sim, acuso-te porque fizeste o não previsto nas leis da amizade e da natureza nem nos deixaste sequer o direito de indagar porque o fizeste, porque te foste.

Carlos Drummond de Andrade 